\title{
Pengaruh Saham Syariah dan Sukuk yang Terdaftar di JII Terhadap Produk Domestik Bruto (PDB) Indonesia Tahun 2015-2019
}

\author{
Rissa Lizah Susanti \\ Institut Pesantren KH. Abdul Chalim Mojokerto Indonesia \\ rissalizah28@gmail.com
}

\begin{abstract}
The background of this research is a phenomenm of Islamic economic financial which is the instrument of bursary effect. It focuses on the grow sharia stock and sukuk that leads to product domestic bruto of certain contry. The sharia stock and sukuk as independent variables and product domestic bruto $(P D B)$ as dependent variables. The object of this research is a secondary data from panel data of sharia stock and sukuk from 2015 to 2019. A quantitative method with association approach was chosen as the method of this research and used doubled linear regression with Eviews 11 programme. The results showed that the sharia stock variables has sig value equal to $0,2409(p>0,05)$ in partially, and it mean that it does not affect to the product domestic bruto $(P D B)$ variables. Meanwhile the sukuk variables has sig value equal to 0,000 $(p<0,05)$, and it affect the product domestic bruto $(P D B)$ variables. In the simultaneously results showed if sharia stock and sukuk variable have sig value equal to 0,000 $(p<0,05)$, it mean affectd the product domestic bruto variables. Furthermore through the $R$ Square test (R2), sharia stock and sukuk variables affect $91 \%$ of the product domestic bruto $(P D B)$ variables and is $9 \%$ affected by other variables that does not included in this research. Key words: sharia stock, sukuk, PDB
\end{abstract}

\begin{abstract}
Abstrak
Penelitian ini dilatarbelakangi oleh fenomena keuangan ekonomi syariah yang merupakan instrumen dari bursary effect. Fokusnya pada tumbuhnya saham dan sukuk syariah yang mengarah pada produk bruto dalam negeri. Saham syariah dan sukuk sebagai variabel bebas dan produk domestik bruto (PDB) sebagai variabel terikat. Objek penelitian ini adalah data sekunder dari data panel saham dan sukuk syariah dari tahun 2015 sampai dengan tahun 2019. Metode penelitian ini menggunakan metode kuantitatif dengan pendekatan asosiasi dan regresi linier berganda dengan 11 program Eviews. Hasil penelitian menunjukkan bahwa variabel saham syariah memiliki nilai sig sebesar $0,2409(p>0,05)$ secara parsial, artinya tidak berpengaruh terhadap variabel produk domestic bruto. Sedangkan variabel sukuk memiliki nilai sig sebesar $0,000(p<0,05)$, dan berpengaruh terhadap variabel produk domestic bruto (PDB). Secara simultan hasil penelitian menunjukkan jika variabel saham syariah dan sukuk memiliki nilai sig sebesar $0,000(p<0,05)$, berarti berpengaruh terhadap variabel produk domestic bruto (PDB). Selanjutnya melalui uji R Square (R2), variabel saham dan sukuk syariah mempengaruhi $91 \%$ variabel produk domestic bruto (PDB) dan 9\% dipengaruhi oleh variabel lain yang tidak termasuk dalam penelitian ini.
\end{abstract}

Kata kunci: saham syariah, sukuk, PDB 


\section{PENDAHULUAN}

Saham syariah sebagai salah satu jenis dari saham biasa pada umumnya, namun perbedaannya dengan saham konvensional yaitu diterapkannya prinsip syariah pada tiap emiten untuk menyaring kehalalan dari jenis barang maupun jenis kegiatan perusahaan agar terhindar dari maysir, gharar, dan riba. Menurut Hidayat, saham syariah merupakan bukti kepemilikan dari suatu emiten yang produk barang, jasa, jenis bisni, akad serta proses pembuatan tidak berlawanan dengan pedoman syariah (Hidayat, 2011:78). Indeks saham dimanfaatkan investor sebagai acuan untuk menjalankan investasi di pasar modal terutama saham. Indonesia mempunyaii tiga indeks saham syariah yaitu Jakarta Islamic Index (JII) meringkingan menjadi 30 saham, Indeks Saham Syariah Indonesia (ISSI) tidak melakukan seleksi dan Jakarta Islamic Index 70 (JII70 meringkingan menjadi 70 saham (OJK, 2019).

Dari ke tiga saham tersebut JII adalah saham terbaik karena hanya terdiri dari 30 saham sayariah terbaik dalam periode yang di tentukan dan tingkat likuiditas yang tinggi. Berikut perkembangan akumulasi emiten saham syariah yang dibukukan dalam Daftar Efek Syariah (DES) dari tahun 2015 sampai dengan 2019:

\section{Gambar 1 \\ Perkembangan Jumlah Emiten Saham Syariah Indonesia 2015-2019}

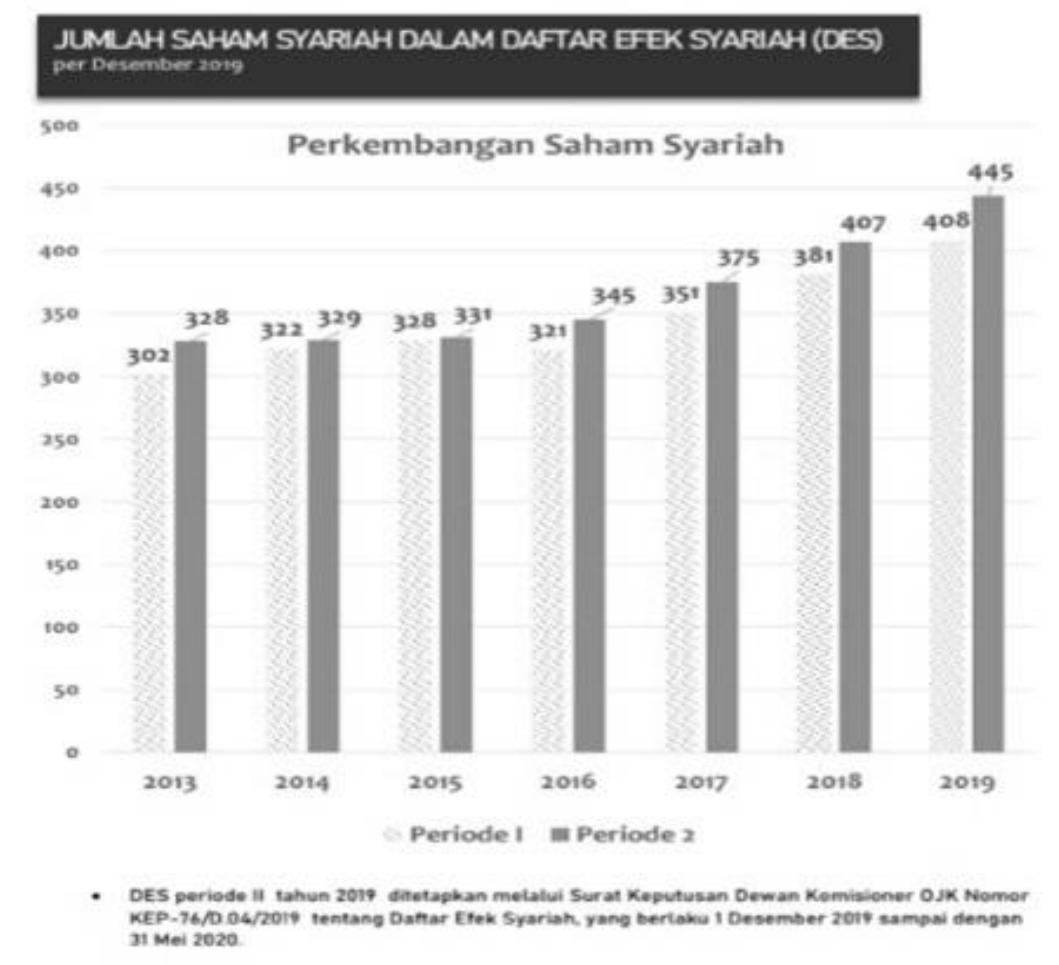

Sumber: $\underline{w w w . o j k . g o . i d}$ 
Table 1

Kapitalisasi Pasar Bursa Efek Indonesia (Rp Dalam Miliar) Tahun 2015-2019

\begin{tabular}{c|c|c}
\hline Tahun & Jakarta Islamic Index (JII) & $\begin{array}{c}\text { Index Saham Syariah } \\
\text { Indonesia (ISSI) }\end{array}$ \\
\hline 2015 & $1.737,29$ & $2.600,85$ \\
\hline 2016 & $2.041,07$ & $3.175,05$ \\
\hline 2017 & $2.288,02$ & $3.704,54$ \\
\hline 2018 & $2.239,45$ & $3.666,07$ \\
\hline 2019 & $2.124,18$ & $3.749,16$ \\
\hline
\end{tabular}

Berlandaskan grafik digambar 1.1 bisa ditunjukkan bahwa perkembangan jumlah emiten saham syariah selama lima tahun terakhir mengalami peningkatan dari tahun 2015 sampai tahun 2019, saham syariah mengalami kenaikan yang bagus dan pertumbuhannya begitu stabil setiap periodenya. Pada tahun 2019, akumulasi saham syariah Indonesia yang tercatat sebanyak 445 saham syariah. Di tahun 2015 akumulasi saham syariah Indonesia yang tercatat sebanyak 331, dalam lima tahun jumlah emiten sudah terdaftar menjadi 445 saham syariah pada tahun 2019. Saham syariah terus berkembang secara signifikan setiap periodenya, meskipun mengalami penurunan di periode 1 tahun 2016.

Perkembangan instrumen pasar modal syariah tidak hanya pada saham syariah saja, namun merambah juga pada produk sukuk atau obligasi syariah. Sukuk perdana diterbitkan pada permulaan September 2002 oleh PT Indosat, Tbk. Penerbitan sukuk pertama kali di tahun 2004 dengan menggunakan akad sewa dan disebut Obligasi Ijarah. Adanya Sukuk ini difungsikan sebagai produk alternatif bagi perusahaan untuk melakukan pembiayaan sesuai dengan syariat dan upaya menghindari praktik maysir (judi), gharar (ketidakpastian), dan riba dalam pembiayaan. 


\section{Gambar 2}

\section{Perkembangan Sukuk Korporasi Outstanding} 2014-2019

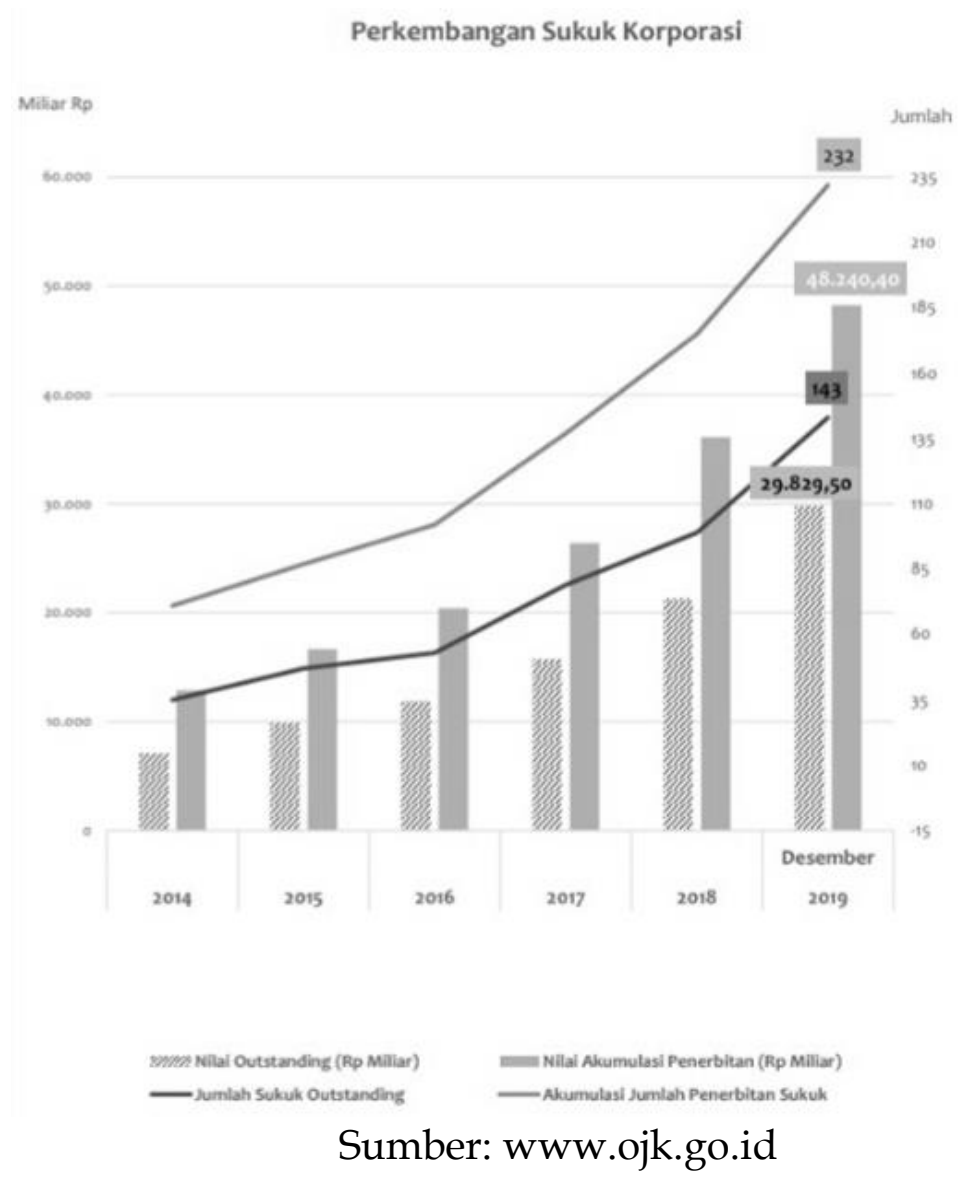

Berlandaskan gambar 1.2 tersebut bisa dilihat bahwa pertumbuhan jumlah sukuk korporasi selama lima tahun terakhir mengalami peningkatan, di tahun 2015 penerbitan sukuk selalu mengalami kenaikan. Dimana bulan September tahun 2019 akumulasi peluncuran sukuk menjadi 232 penerbitan. Akumulasi outstanding sukuk atau sukuk yang masih beredar menjadi 143 sukuk pada tahun 2019. Dari tahun 2015 sampai dengan tahun 2019, emisi sukuk mengalami kenaikan lebih dari 4 kali lipat, yakni dari Rp.11.994,4 triliun pada tahun 2015 menjadi sebesar Rp.48.240,40 triliun pada tahun 2019. Sampai dengan tahun 2019 nilai outstanding meningkat sebesar 24,78\% menjadi sebesar Rp31,14 triliun.

Salah satu faktor pentingnya keberadaan pasar modal dalam suatu negara adalah untuk mengukur tingkat pertumbuhan ekonomi diaman nantinya menggunakan pendapat ekonomi, kontribusi pendanaan sangat dibutuhkan pemerintah dalam sebagai upaya untuk pengembangan negara menjadi lebih baik dan efektif serta efisien. Menurut Mankiw reliabilitas pasar 
saham merupakan istilah lain pasar modal sebagai indikator ekonomi (Shodiqurrosyad, 2014:10). Ukuran perkembangan ekonomi secara langsung dihitung dengan data pendapatan nasional riil yang ada. Nainggolan menyatakan, jika pertumbuhan ekonomi berhubungan dengan output per kapita dengan mengawasi dua hal, yakni output total (Produk Domestik Bruto (PDB) setra akumulasi penduduk, sebab output per kapita merupakan output total dibagi dengan akumulasi penduduk (Larasati dan Sulasmiyati, 2018:9). Mankiw memaparkan pentingnya peduli dengan Produk Domestik Bruto (PDB), sebab negara yang Produk Domestik Bruto (PDB) lebih besar bisa mengfasilitasi sistem pendidikan, perawatan kesehatan serta bisa memperkirakan kapasitas negara guna memperoleh unsur-unsur yang membentuk sebuah hidup yang berarti (Larasati dan Sulasmiyati, 2018:9). Berikut perkembangan PDB tahun 2015 sampai dengan 2019:

\section{Tabel 2}

Perkambangan PDB Indonesia (Dalam Persen) Tahun 2015-2019

\begin{tabular}{l|l|l|l|l|l}
\hline Tahun & 2015 & 2016 & 2017 & 2018 & 2019 \\
\hline PDB & 4,8 & 5,03 & 5,07 & 5,17 & 5,02 \\
\hline \multicolumn{6}{c}{ Sumber: www.bps.go.id }
\end{tabular}

Berlandaskan tabel 1.2 tersebut dilihat bahwa PDB selama lima tahun terakhir mengalami peningkatan dari tahun 2015 sampai periode I tahun 2019 bekembang dengan baik di setiap periodenya, dimana tahun 2015 memiliki presentase sebesar 4,8\% dan sampai tahun 2018 memiliki presentase sebesar $5,17 \%$, meskipun mengalami penurunan dengan presentase sebesar 5,06\% di periode I tahun 2019.

\section{METODE PENELITIAN}

Penelitian ini menerapkan penelitian kausalitas yang berdasarkan kejadian sebab-akibat (Siyoto, 2015:100). Data yang digunakan adalah data gabungan antara time series dengan cross section. Populasi yang digunakan dalam penelitian ini adalah semua perusahaan yang terdaftar di JII pada periode pengamatan 2015 sampai 2019 dan peneliti menemukan sebanyak 46 perusahaan, dan sampel yang digunakan dalam penelitian ini yaitu seleuruh data saham syariah dan sukuk dari tahun 2015-2019.

\section{PEMBAHASAN}

A. Hasil Analisis Data

Pengujian hipotesis dijalankan guna melakukan uji pada hipotesis dalam penelitian ini, menggunakan tiga model uji hipotesis yaitu Uji t, Uji F dan Koefisien Determinasi $\left(\mathrm{R}^{2}\right)$. 


\section{Uji T}

Berikut adalah hasil dari uji $\mathrm{T}$ (Parsial) dengan memakai model estimasi fixed Effect pada penelitian ini:

Tabel 3

Hasil Uji t-statistic

\begin{tabular}{|c|c|c|c|c|}
\hline Variable & Coefficient & $\begin{array}{l}\text { Std. } \\
\text { Error }\end{array}$ & t-Statistic & Prob. \\
\hline $\mathrm{C}$ & 2001.950 & $\begin{array}{c}77.787 \\
51\end{array}$ & 25.73614 & 0.0000 \\
\hline SAHAM_SYARIAH? & 0.048527 & $\begin{array}{c}0.0396 \\
28\end{array}$ & 1.224578 & 0.2409 \\
\hline SUKUK? & 0.023621 & $\begin{array}{c}0.0020 \\
87\end{array}$ & 11.31703 & 0.0000 \\
\hline \multicolumn{5}{|l|}{ Fixed Effects (Cross) } \\
\hline $1-\mathrm{C}$ & -46.86697 & & & \\
\hline $2-C$ & 19.91893 & & & \\
\hline $3-C$ & 59.34323 & & & \\
\hline $4-C$ & -32.39519 & & & \\
\hline
\end{tabular}

Sumber: Data diolah peneliti 2020

\section{Saham Syariah}

Berdasarkan hasil pengujian bisa dilihat dari tabel 4.7 jika variabel saham sayariah (X1) mempunyai nilai signifikansi sebanyak 0.2409 yang lebih banyak dari pada 0,05 ( $\mathrm{p}>0,05)$, dari hasil penelitian tersebut memaparkan secara parsial variabel saham syariah (X1) tidak berpengaruh terhadap PDB (Y). Terjadinya hal semacam ini disebabkan adanya fluktuasi harga saham yang berdampak pada perolehan saham syari'ah yang bisa berdampak pada PDB pula, sebab laju ekonomi menjadi penentu kemajuan perekonomian. Pada tahun terakhir ini PDB Indonesia mengalami kenaikan meskipun di tahun 2019 mengalami penurunan karena adanya pertumbuhan negatif yang terjadi di semua komponen PDB (BPS, 2020).

Indikator dari penyusutan ekonomi tergambar pada menyusutnya nilai saham yang berdampak terhadap penurunan penghasilan saham tersebut. Secara teori bisa dipaparkan bahwa naiknya PDB bisa menaikkan kemampuan beli konsumen terhadap produk perusahaan, 
alhasil bisa menaikkan profitabilitas perusahaan. Akibat kenaikan profitabilitas bisa menaikkan investor dalam kegiatan berinvestasi, jadi bisa menambah nilai saham yang berpengaruh positif juga. Pendapatan dari saham syari'ah sendiri masih dalam ruang lingkup dari kriteria perusahaan syari'ah, sehingga dalam pengaruhnya terhadap PDB tidak secara langsung atau menyeluruh.

Penelitian ini sejalan dengan teori Syarir jika harga saham syariah dipengaruhi oleh beberapa faktor diantaranya makro ekonomi dan moneter, di sisi internal dipengaruhi oleh keamanan, politik, kebijakan pemerintah (Muharrami dkk., 2017:177). Keadaan seperti faktor internal dan eksternal seharusnya bisa diatasi oleh emiten dan pemerintahan agar iklim investasi saham syariah terjaga dengan baik dan bisa membuat para investor baik dalam negeri ataupun asing untuk tetap percaya untuk menanamkan modalnya di Indonesia.

\section{Sukuk}

Berdasarkan hasil pengujian bisa diketahui dari tabel 4.7 jika variabel sukuk (X2) mempunyai nilai signifikansi sebesar 0.0000 yang lebih kecil dari pada $0,05(\mathrm{p}<0,05)$, dari hasil penelitian tersebut menunjukkan bahwa secara parsial variabel sukuk (X2) berpengaruh terhadap PDB (Y). Sebab sukuk berguna bagi pihak negara berfungsi untuk alat keperluan memobilisasi modal dan sebagai media guna memupuk partisipasi pihak swasta dalam mendanai proyek kepentingan publik, sebagai instrumen guna mendorong investasi dalam negeri ataupun negara asing. Sukuk bisa difungsikan sebaga alat mobilisasi dana yang dimaksudkan sebagai sumber pengucuran dana guna pembangunan infrastruktur seperti jembatan, jalan dan fasilitas umum masyarakat lainnya dan pertumbuhan ekonomi nasional, meskipun tingkat presentasinya lebih sedikit dari pada sukuk negara.

Bagi swasta sukuk bisa berguna sebagai alternatif pendanaan dan berperan menjadi produk kerja sama modal dalam pengembangan firma karena penjualan sukuk pada investor akan membuat modal perusahaan bertambah dan akan di pergunakan perusahaan untuk lebih produktif lagi dalam memproduksi barangnya yang akan menjadi output yang lebih banyak dari sebelumnya dan di harapkan mendapatkan keuntungan melebihi sebelumnya. Sukuk juga akan memberikan fasilitas bagi firma dalam kesiapan pilihan institusi yang bermacam-macam bagi tiap produk keuangan untuk menentukan instrument mana yang akan investor pilih sebagai tempat penanaman modal yang dimiliki. 


\section{Uji simultan (F statistic)}

Berikut adalah hasil dari uji $\mathrm{F}$ (simultan) dengan memakai model estimasi Fixed Effect pada penelitian ini:

Tabel 4

Hasil Uji F-statistik

\begin{tabular}{l|l}
\hline F-statistic & 39.65920 \\
\hline Prob(F-statistic & 0.000000 \\
\hline
\end{tabular}

Sumber: Data diolah peneliti 2020

Berdasarkan hasil pengujian bisa dilihat dari tabel 4.6 jika kedua variabel independen yaitu saham syariah (X1) dan sukuk (X2) mempunyai nilai signifikansi sebanyak 0,000000 yang lebih rendah dari pada $0,05(\mathrm{p}<0,05)$, dari hasil penelitian tersebut memaparkan jika dengan cara simultan kedua variabel independen yaitu saham syariah (X1) dan sukuk (X2) berpengaruh terhadap PDB (Y). Hasil penelitian ini sejalan dengan teori Tendelilin bahwa pertumbuhan PDB yang cepat menjadi salah satu indikator terjadinya pertumbuhan ekonomi, jika pertumbuhan ekonomi membaik makan perekonomian masyarakat juga naik dan kemampuan beli juga akan naik. Signifikansi yang terjadi karena PDB yang terus membaik selama lima tahun ini maka kemampuan beli masyarakat ikut naik dan hal ini menjadi peluang bagi perusahaan untuk mengoptimalkan kinerjanya terlebih dalam penjualan (Selvianty, 2015:6).

\section{Koefisien Determinasi $\left(\mathbf{R}^{2}\right)$}

Berikut hasil dari uji koefisien determinasi $\left(R^{2}\right)$ dengan menggunakan model estimasi fixed Effect pada penelitian ini:

\begin{tabular}{cc}
\multicolumn{2}{c}{ Tabel 5} \\
Hasil Uji Koefisien Determinasi \\
\hline R-squared & 0.934054 \\
\hline Adjusted R-squared & 0.910502 \\
\hline \multicolumn{2}{l}{ Sumber: Data diolah peneliti 2020}
\end{tabular}

Berdasarkan table 4.8 bisa dipaparkan jika nilai Adjusted $R$-squared sebesar 0.910502 atau $91 \%$ berarti dua variabel independen yaitu Saham Syariah (X1) dan Sukuk (X2) yang terdaftar di JII mempengaruhi PDB Indonesia $91 \%$ dan 9\% lainnya dari faktor variabel lainnya di luar 
penelitian ini, bisa disimpulkan jika model regeresi sangat baik untuk digunakan.

\section{KESIMPULAN}

Berasaskan pembahasan hasil penelitian yang sudah dijalankan terkait dengan pengaruh saham syariah dan sukuk terhadap PDB, maka mampu menarik beberapa kesimpulan sebagai berikut:

1. Secara parsial, variabel saham syariah memiliki Sig 0,262>0,05 dari hasil tersebut menjelaskan bahwa variabel saham syariah tidak berpengaruh terhadap PDB.

2. Secara parsial, variabel sukuk memiliki Sig $0.0000<0,05$ dari hasil tersebut menjelaskan bahwa variabel sukuk berpengaruh terhadap PDB.

3. Secara simultan, diperoleh nilai Sig 0,000<0,05 bisa diartikan bahwa variabel saham syariah dan sukuk berpengaruh secara barsama-sama terhadap PDB.

\section{DAFTAR PUSTAKA}

Anwar, Jusuf. Pasar Modal Sebagai Sarana Pembiayaan dan Investasi. Bandung: PT. Alumni, 2008.

Arif, Dodi. Pengaruh Produk Domestik Bruto. Jumlah Uang Beredar, Inflasi dan BI Rate Terhadap Indeks Harga Saham Gabungan di Indonesia Periode 2007 - 2013. Depok: Universitas Gunadarma, 2013.

BPS. “Berita Resmi Statistik", dalam www.bps.go.id (18 Juni 2020).

BPS. “PDB Indonesia Triwulan 2015-2018”, dalam www.bps.go.id (10 Agustus 2020).

CNBC Indonesia, “Ojk Enam Alasan Investasi Di Indonesia Masih Menarik”, dalam

https:// www.cnbcindonesia.com/investment/20180319110516-217689/ojk-enam-alasan-investasi-di-indonesia-masih-menarik （ 26 Desember 2019).

Faiza, Nurlaili Adkhi Rizfa dan Shafiyatun. "Pengaruh Nilai Outstending Sukuik Korporasi terhadap PDB Indonesia (Periode Triwulan 20112017)", El-Qist, Vol. 08, No. 01, April 2018, 1592.

Ghozali and Ratmono. Analisis Multivariat dan Ekonometrika Teori, Konsep dan Aplikasi dengan Eviews 10. Ponegoro: Undip, 2017.

Hamidi, M. Luthfi. Jejak-Jejak Ekonomi Syariah. Jakarta: Senayan Abadi Publishing, 2003.

Irawan dan Zulia Almaida Siregar. Pengaruh Saham Syariah, Sukuk dan Reksadana Syariah Terhadap Pertumbuhan Ekonomi Indonesia (Tahun 2012 - Tahun 2017). Tansiq, Vol. 2, No. 1, (Januari - Juni 2019), 23-26. 
Irsyad, Muhammad. Et al. Pengaruh PDB (Produk Domestik Bruto), Suku Bunga, dan Inflasi Terhadap Profitabilitas Bank Syariah Periode 20142017. Tafaqquh: Jurnal Hukum Ekonomi Syariah dan Ahwal As Syakhsiyah, 59.

Kartika, Kharissa Dinna. Pengaruh Saham Syariah, Obligasi Syariah, Reksadana Syariah, dan Inflasi Terhadap Pertumbuhan Ekonomi Indonesia Periode 2011-2017. Salatiga: Institut Agama Islam Negeri, 2019.

Larasati, Irene Sarah dan Sri Sulasmiyati. Pengaruh Inflasi, Ekspor, dan Tenaga Kerja Terhadap Produk Domestik Bruto (PDB) (Studi Pada Indonesia, Malaysia, Singapura, dan Thailand). Jurnal Administrasi Bisnis, Vol. 63, No. 1, Oktober 2018, 9.

Muhamad. Metodologi Penelitian Ekonomi Islam Pendekatan Kuantitatif Edisi 1. Jakarta: PT Raja Grafindo Persada.

Muharrami, Rais Sani. Et.al. Pergerakan Harga Saham Syariah Pada Saham Bank Syariah Dilihat Dari Faktor Makro Ekonomi. Bisnis, Vol. 5, No. 1, Juni 2017, 177.

OJK, "Indeks Saham Syariah", dalam www.idx.co.id (28 November 2019).

OJK. “Laporan Triwulan III 2019”, dalam www.ojk.go.id (10 Agustus 2020).

Selvianty, Inneke. Analisis Indikator Makro Ekonomi Terhadap Pertumbuhan Sukuk di Indonesia, Malang: Universitas Maulana Malik Ibrahim, 2015.

Shodiqurrosyad, Ahmad. Pengaruh Pasar Modal Syariah Terhadap Pertumbuhan Ekonomi Indonesia (Analisis Kasus Tahun 2000-2012), Surabaya: Universitas Islam Negeri Sunan Ampel, 2014.

Siyoto, Sandu. Et.al. Dasar Metodologi Penelitian. Karanganyar: Literasi Media Publishing, 2015.

Sugiyono. Metode Penelitian Kuantitatif, Kualitatif, Dan R\&D. Bandung: Alfabeta, 2011.

Tabdelilin, Eduardus. Analisis Investasi dan Manejemen Portofolio. Yogyakarta: UUP AMPYKPN, 2005.

Taufik Hidayat, Buku Pintar Investasi Syariah (Jakarta Selatan: Mediakita, 2011),

Widarjono, Agus. Ekonometrika: Teori Dan Aplikasi Untuk Ekonomi dan Bisnis, Yogyakarta: Ekonosia, 2009.

Yuliana, Indah. Investasi Produk Keuangan Syariah. Malang: UIN-Malik Press, 2010. 